\title{
ENCIT1-2020-0144 \\ INCREASING THE HYDROPOWER GENERATION AT THE RIO DAS ANTAS WITH SEASONAL PUMPED HYDROPOWER STORAGE
}

\section{Julian David Hunt}

International Institute for Applied Systems Analysis, Schlossplatz 1, A-2361, Laxenburg, Austria

hunt@iiasa.ac.at

Natália de Assis Brasil Weber

natalia.weber@ufrgs.br

Lara Werncke Vieira

larawv@outlook.com

Paulo Smith Schneider

Programa de Pós-Graduação em Engenharia Mecânica, Universidade Federal do Rio Grande do Sul, Rua Sarmento Leite, 425 - Sala 202, Centro Histórico - 90040-001, Porto Alegre, Brazil

pss@ mecanica.ufrgs.br

Abstract. The increase in intermittent sources of electricity in national grids is increasing the need for energy storage solutions. Brazil's energy grid has a hydrothermal conformation that the provision of power to meet the demand is easily met with its numerous hydropower generators if there is water available to turn their turbines. With the intent of storing water and energy with a small flooded area for a whole cascade of hydropower plants, this paper proposes the construction of a new seasonal pumped storage plant (SPHS), named São Tomé SPHS, at the head of the Antas river in the Rio Grande do Sul state. Results show that the proposed SPHS plant would increase the hydropower in the dams in cascade in around $260 \mathrm{MW}$. Apart from this, the SPHS plant could also be used to store energy generated from solar and wind sources and generate electricity during peak hours.

Keywords: Seasonal Hydropower Pumped Storage, Energy Storage, Water Management, Hydropower, Renewable Energies.

\section{INTRODUCTION}

The development of a sustainable future requires better management of energy and water resources. New resource management approaches and the UN's Sustainable Development Goals (SDGs) (Griggs et al. 2013) have been focusing on the need to optimize interactions between water, energy and land, to provide society and the economy with the required resources at an affordable cost, while minimizing the adverse impacts on the environment (Rasul and Sharma 2016; Ringler, Bhaduri, and Lawford 2013). Water resources are essential for the development of society, industry, irrigation, transportation, recreation, and hydropower generation. Storage reservoirs play an important role to manage water resources across a basin and between time periods. However, storage reservoirs require appropriate geological formations that allow the reservoir level to vary significantly for storing a considerable amount of water.

A reliable balance between energy supply and demand is facing more challenges with the integration of intermittent renewable energy sources such as wind and solar (Huertas-Hernando et al. 2017). This has led to a growing demand for flexibility options such as energy storage (Schill and Zerrahn 2018). These variable energy sources have hourly, daily and seasonal variations, which require back-up and balancing technologies to maintain a secure supply. Currently, most pumped-hydro storage (PHS) plants only store energy in daily storage cycles, however, this might not be competitive in the future due to the reduction in battery costs (I. Kougias and Szabó 2017). Other reviews on PHS types can be seen in (NHA 2017; Dallinger et al. 2019; Ioannis Kougias et al. 2019; Julian David Hunt et al. 2020; International Hydropower Association 2019; Kong et al. 2017; J. Hunt et al. 2018; J.D. Hunt, Freitas, and Pereira Junior 2017).

This paper presents the benefits of constructing a seasonal pumped storage plant on the Antas River, particularly with the construction of the São Tomé SPHS plant. Apart from storing energy from intermittent sources and generating electricity during peak hours, this plant has the potential to reduce the spillage in the dams downstream and, thus, increase their hydropower generation and store water in case of draughts (J.D. Hunt., Stilpen, and de Freitas 2018). 


\section{METHODOLOGY}

SPHS consists of two reservoirs, a lower and an upper reservoir connected by a power conversion system (pump/turbine) and a tunnel Figure 1 (a). The lower reservoir is meant for storing water and it may or may not have a large storage capacity (Julian David Hunt et al. 2020). Typically, a month-long storage capacity in the lower reservoir is enough to store water in days with intense rainfall, allowing the water in the main river to be pumped to the upper reservoir. The upper reservoir should have a large storage capacity to take up a large part of the water from the main river during periods with high flowrate, and store the water periods with low river flow or droughts. Thus, most of the water will be stored in the upper reservoir and the lower reservoir would control flow fluctuation in the main river so that water will be available to be pumped to the upper reservoir.
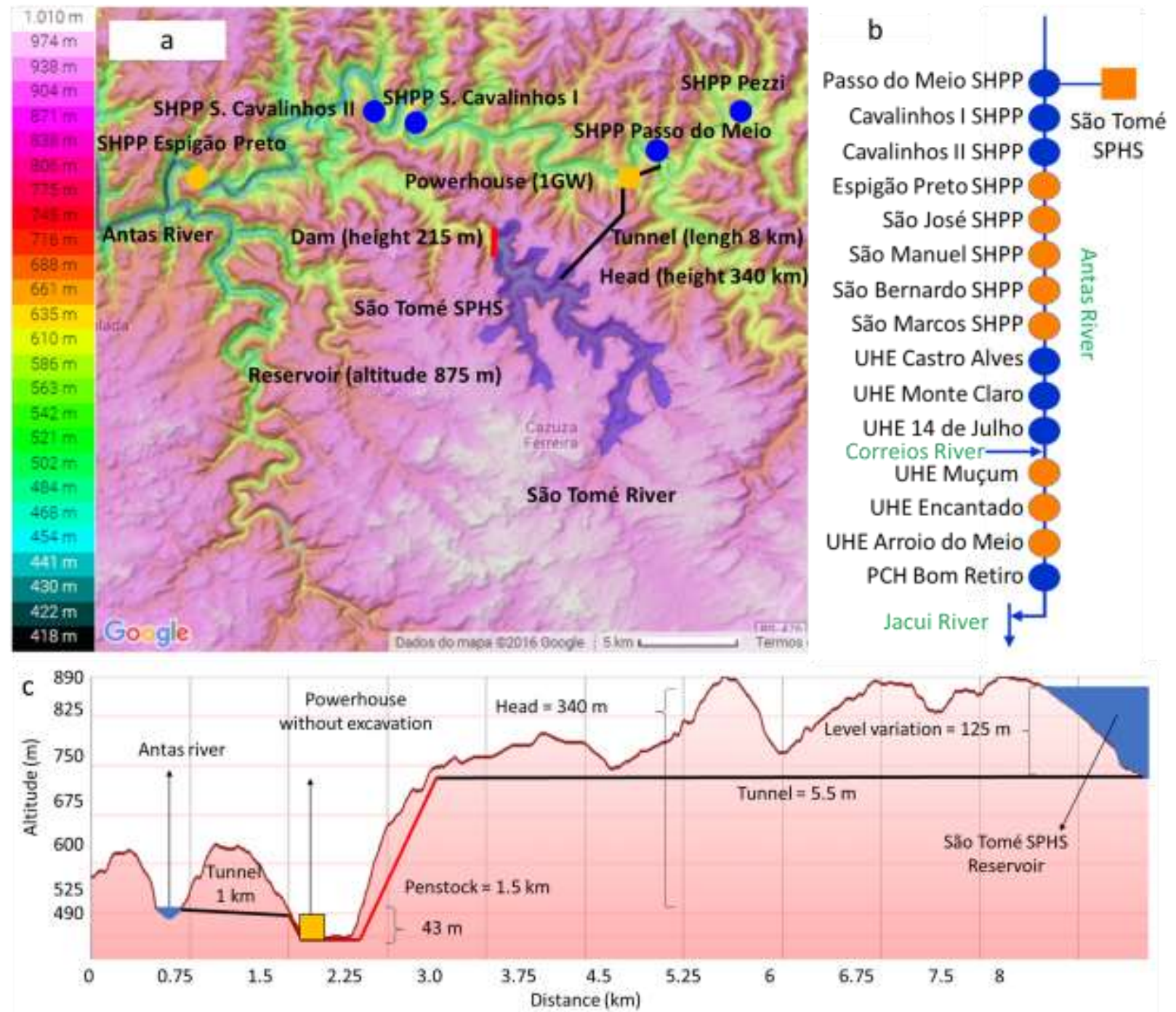

Figure 1. (a) São Tomé SPHS project description in the head of the Antas river. (b) Antas river cascade with operational (blue) and planned (orange) run-off-the-river (circles) plants and proposed SPHS (square) plant. SHPP are small hydropower plants (smaller than $50 \mathrm{MW}$ ) and LHPP are large hydropower plants (larger than $50 \mathrm{MW}$ ). (c) Axial presentation of the São Tomé SPHS. 


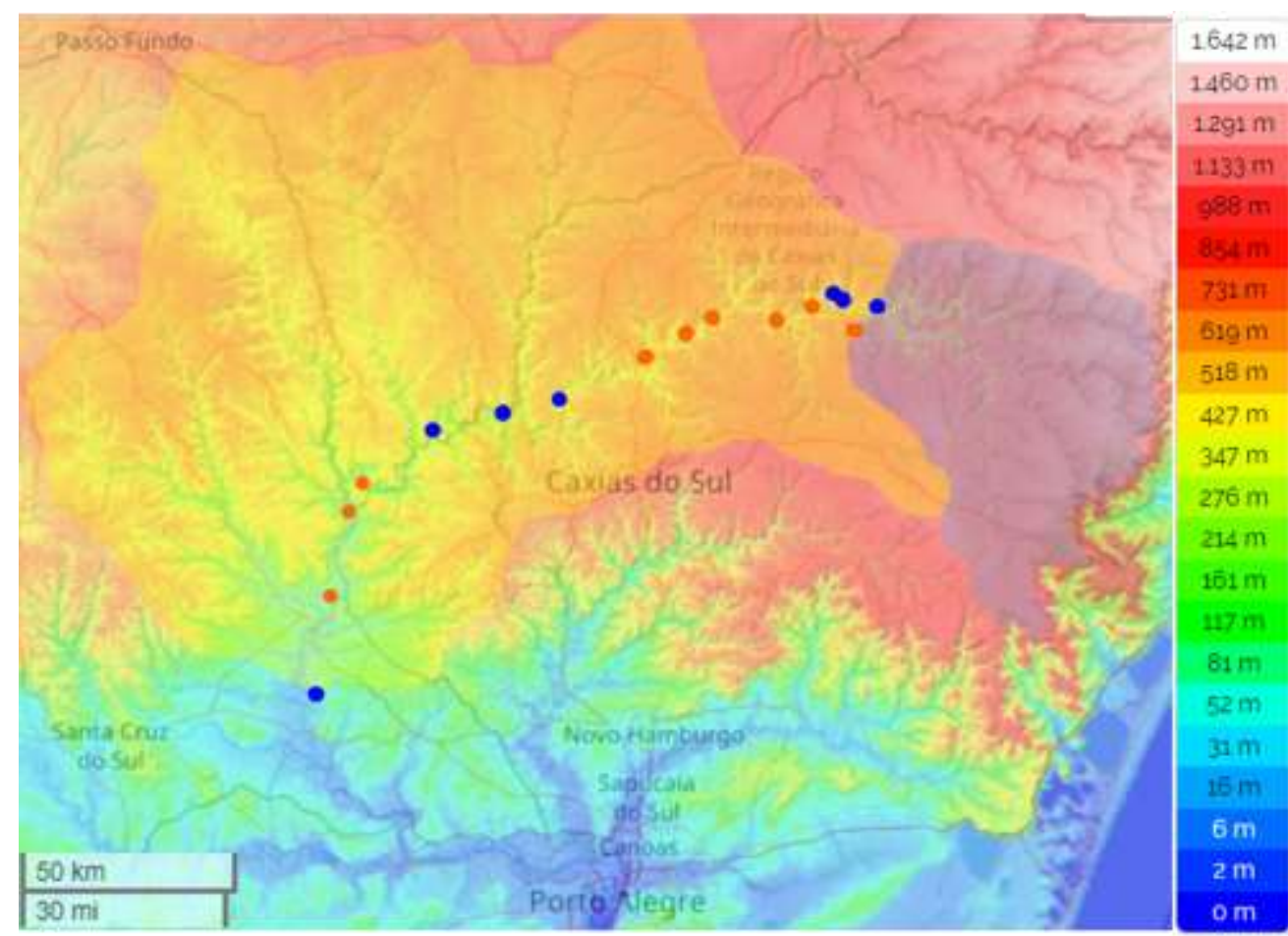

Figure 2. Antas river basin with São Tomé SPHS. The blue area represents the drainage area of São Tomé SPHS. The yellow area represents the drainage area of the other plants in the basin.

The São Tomé SPHS plant proposed for the Antas river has the potential to regulate the flow of the Antas and Taquari rivers. The São Tomé SPHS dam can vary between 140 to 215 meters and the necessary tunnel is $5 \mathrm{~km}$, as shown in Figure 1 (a). The São Tomé SPHS powerhouse is at a height of approximately $490 \mathrm{~m}$ Figure 1 (c), since the water collection takes place in the reservoir of the Passo do Meio small hydropower plant (SHPP) at an altitude of 535 $\mathrm{m}$. This results on a 45 meters head, which is enough to prevent cavitation of São Tomé SPHS. In other words, São Tomé SPHS has a benefit in that it does not require excavating the powerhouse, which would reduce its cost by approximately $10 \%$. Figure 1 (b) shows the cascade of plants in the Antas river basin. Figure 2 shows the SHPS and the run-off-the-river plants in Antas and Taquari rivers, focusing on the drainage area of São Tomé SPHS is $3,734 \mathrm{~km}^{2}$ (in blue) and the drainage area of the other plants in the basin is $26,428 \mathrm{~km}^{2}$ (in yellow). Table 1 and Table 2 presents the details of the operational and planned, small hydropower plants (SHPP) and large hydropower plants (LHPP) downstream the São Tomé SPHS plant, respectively.

Table 1. Description of SHPP in operation and planning that will benefit from São Tomé SPHS.

\begin{tabular}{|c|c|c|c|c|c|c|c|c|}
\hline & \begin{tabular}{|c|}
$\begin{array}{c}\text { Passo do } \\
\text { Meio }\end{array}$ \\
\end{tabular} & $\begin{array}{c}\text { Serra dos } \\
\text { Cavalinhos I }\end{array}$ & \begin{tabular}{c|} 
Serra dos \\
Cavalinhos II
\end{tabular} & $\begin{array}{c}\text { Espigão } \\
\text { Preto }\end{array}$ & São José & $\begin{array}{c}\text { São } \\
\text { Manuel }\end{array}$ & $\begin{array}{c}\text { São } \\
\text { Bernardo }\end{array}$ & $\begin{array}{c}\text { São } \\
\text { Marcos }\end{array}$ \\
\hline Status & Operating & Operating & Operating & Planned & Planned & Planned & Planned & Planned \\
\hline Power (MW) & 30 & 25 & 29 & 34 & 30 & 51 & 30 & 57 \\
\hline Upstream level (m) & 535 & 477.5 & 450 & 419 & 380 & 350 & 305 & 282 \\
\hline Downstream level (m) & 492 & 450.28 & 418.8 & 382 & 353 & 305 & 283 & 241 \\
\hline Head (m) & 43 & 27.22 & 31.2 & 37 & 27 & 45 & 22 & 41 \\
\hline Area $\left(\mathrm{km}^{2}\right)$ & 2.48 & 0.95 & 0.48 & 2.1 & 0.43 & 2.6 & 0.6 & 2.3 \\
\hline Drainage area $\left(\mathrm{km}^{2}\right)$ & 3,457 & 3,703 & 3,809 & 4,255 & 5,247 & 6,379 & 6,433 & 6,902 \\
\hline $\begin{array}{l}\text { Impact of São Tomé } \\
\text { SPHS on drainage area } \\
(\%)\end{array}$ & 1.10 & 1.03 & 1.00 & 0.89 & 0.72 & 0.60 & 0.59 & 0.55 \\
\hline
\end{tabular}

Table 2. Description of the LHPP in operation and planning that will benefit from the São Tomé SPHS.

\begin{tabular}{|l|c|c|c|c|c|c|c|}
\hline & $\begin{array}{c}\text { Castro } \\
\text { Alves }\end{array}$ & $\begin{array}{c}\text { Monte } \\
\text { Claro }\end{array}$ & $\begin{array}{c}14 \text { de } \\
\text { Julho }\end{array}$ & Muçum & Encantado & $\begin{array}{c}\text { Arroio do } \\
\text { Meio }\end{array}$ & $\begin{array}{c}\text { Bom } \\
\text { Retiro }\end{array}$ \\
\hline Status & Operating & Operating & Operating & Planned & Planned & Planned & Operating \\
\hline Power (MW) & 130 & 130 & 100 & 79.5 & 36.2 & 68.6 & 35.2 \\
\hline Upstream level (m) & 240 & 148 & 104 & 65 & 38.5 & 30 & 12.3 \\
\hline
\end{tabular}




\begin{tabular}{|l|c|c|c|c|c|c|c|}
\hline Downstream level $(\mathrm{m})$ & 148 & 104 & 70.5 & 38.5 & 30 & 13.5 & 2.85 \\
\hline Head $(\mathrm{m})$ & 92 & 44 & 33.5 & 26.5 & 8.5 & 16.5 & 9.45 \\
\hline Area $\left(\mathrm{km}^{2}\right)$ & 5 & 1.4 & 5 & 9.7 & 2.6 & 11.4 & 6.73 \\
\hline Drainage area $\left(\mathrm{km}^{2}\right)$ & 7,776 & 12,132 & 12,775 & 15,839 & 19,138 & 19,536 & 26,428 \\
\hline
\end{tabular}

The equation is used to estimate the energy stored in the SPHS plant.

$$
\text { EnergyStored }=\sum_{i=1}^{n} h_{i} f_{i} c_{i} g \rho
$$

Where, "Energy Stored" is measured in Joules $(\mathrm{J}) ; h$ is the mean difference in height between the upper reservoir and the lower reservoir plus the sum of the generation head of the dams in cascade (in meters); $n$ is the number of dams in cascade dams and the SPHS; $f$ is the amount of water stored in the SPHS plant (in $\left.\mathrm{m}^{3}\right) ; c$ is the efficiency of the dams in cascade and the SPHS; $g$ is the acceleration due to gravity (in $\mathrm{m} / \mathrm{s}^{2}$ ); $\rho$ is the density of water (in $\mathrm{kg} / \mathrm{m}^{3}$ ). The volume of water stored in the SPHS is estimated using the topography of the site. The overall efficiency of the system is estimated using Eq. 2 below (J.D. Hunt, Freitas, and Pereira Junior 2014).

$$
\text { Overall Efficiency }=\frac{\left(H_{S P S}+H_{j}-0.25 \times H_{S P S}\right) \times F \times g+V+E}{\left(H_{S P S}+H_{j}\right) \times F \times g}
$$

Where:

$F=$ Pumping flow in the SPHS $\left(\mathrm{m}^{3} / \mathrm{s}\right)$.

$H_{S P H S}=$ SPHS mean generation head (meters).

$H_{j}=$ Generation head in the hydroelectric plants, downstream the SPHS (meters).

$V=$ Electricity generation gains due to the reduction of spillage (in $\mathrm{kWh}$ )

$E=$ Electricity generation gains due to reduced evaporation (in $\mathrm{kWh}$ )

$g=$ gravitational acceleration $\left(\mathrm{m} / \mathrm{s}^{2}\right)$.

Although a daily SPHS has an average efficiency of $80 \%$, the combination of a SPHS and a cascade of hydroelectric dams can increase the total storage efficiency to about $95 \%$, not including the reduction of spillage in cascading dams. In cases where a SPHS reduces the spillage in the hydroelectric dams in cascade, the SPHS may result in an overall energy gain, rather than a loss to the system. For example, the São Tomé SPHS can have an overall efficiency of $105 \%$ or higher.

\section{RESULTS}

In order to accurately estimate the volume of the São Tomé SPHS reservoir, the topographic data from the Shuttle Radar Topography Mission (SRTM) were used (Jarvis A., H.I. Reuter, A. Nelson 2008). An area of the reservoir was defined and the variation in volume of the topography represents a variation in the volume of the reservoir of the São Tomé SPHS, as shown in Figure 3. 

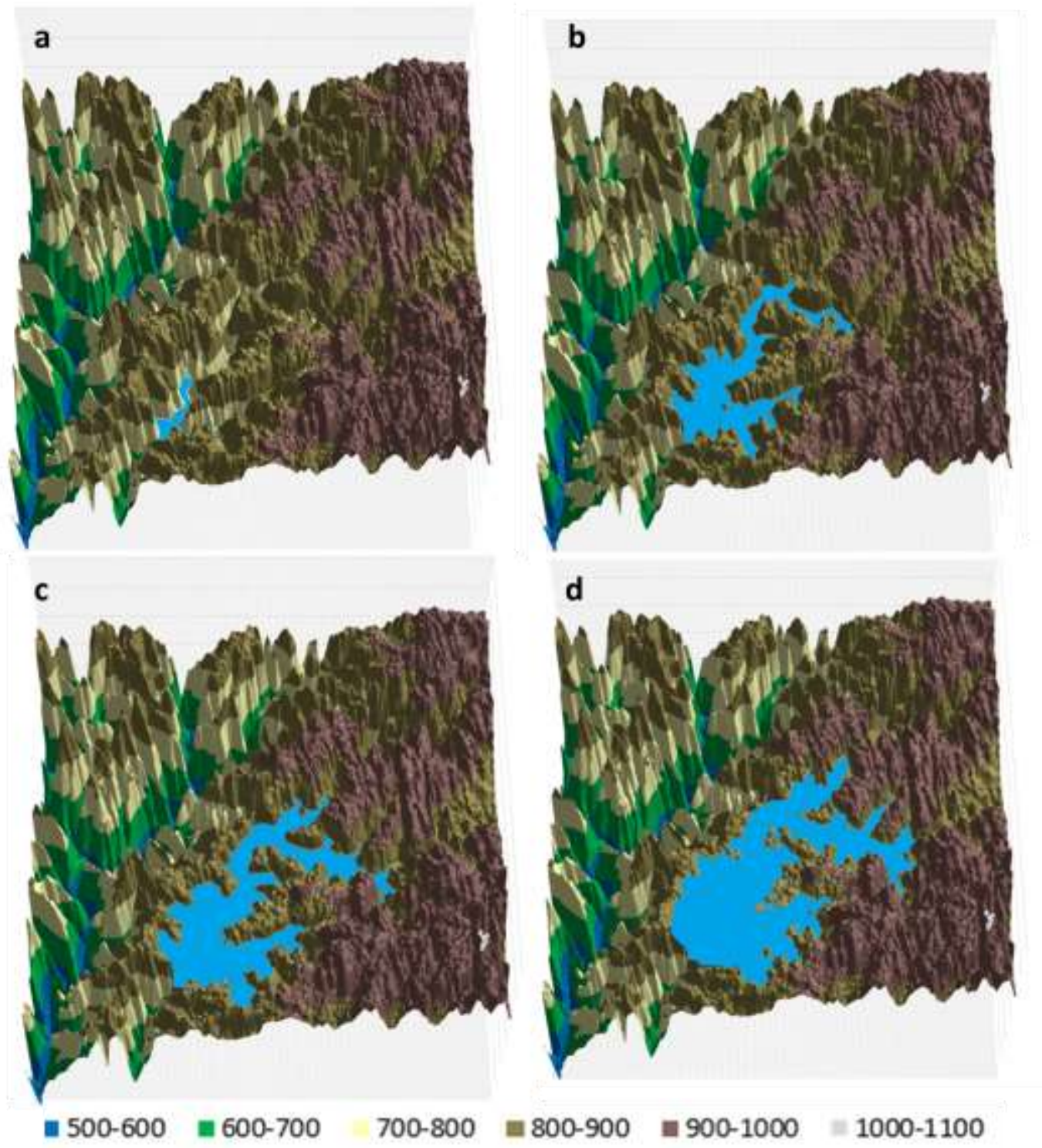

Figure 3. São Tomé SPHS reservoir with dimensions of (a) 740, (b) 800, (c) 850, (d) 875 meters.

Three examples of dams have been proposed for the São Tomé SPHS (Figure 4). The highest proposed dam for the São Tomé SPHS reaches an altitude of $875 \mathrm{~m}$, which requires a $215 \mathrm{~m}$ high and $4 \mathrm{~km}$ dam, and a flooded area of 49 $\mathrm{km}^{2}$. Note that a $2.5 \mathrm{~km}$ section of the dam has an altitude of less than 25 meters, which would not be an impediment to the project. The resulting reservoir can store $2.7 \mathrm{~km}^{3}$ of water and $5.5 \mathrm{GWmed}$ of energy. The intermediate proposed dam for the São Tomé SPHS is $850 \mathrm{~m}$, which required a $190 \mathrm{~m}$ high and $1.5 \mathrm{~km}$ long dam, and a flooded area of 33 $\mathrm{km}^{2}$. The resulting reservoir would be able to store $1.7 \mathrm{~km}^{3}$ of water and $3.4 \mathrm{GWmed}$ of energy. The lowest proposed dam for the São Tomé SPHS is $800 \mathrm{~m}$, which requires a $140 \mathrm{~m}$ high and $1 \mathrm{~km}$ long dam, and a flooded area of $15 \mathrm{~km}^{2}$. The resulting reservoir would be capable of storing $0.6 \mathrm{~km}^{3}$ of water and $1.3 \mathrm{GWmed}$ of energy. Figure 5 presents the level vs. storage volume of the São Tomé SPHS. As it can be seen, the amount of water storage capacity substantially increases with the increase in dam altitude. This allows a great deal of water to be stored in a small land area. Table 3 presents the general benefits for SHPP and LHPP in Antas river with the construction of the São Tomé SPHS. 

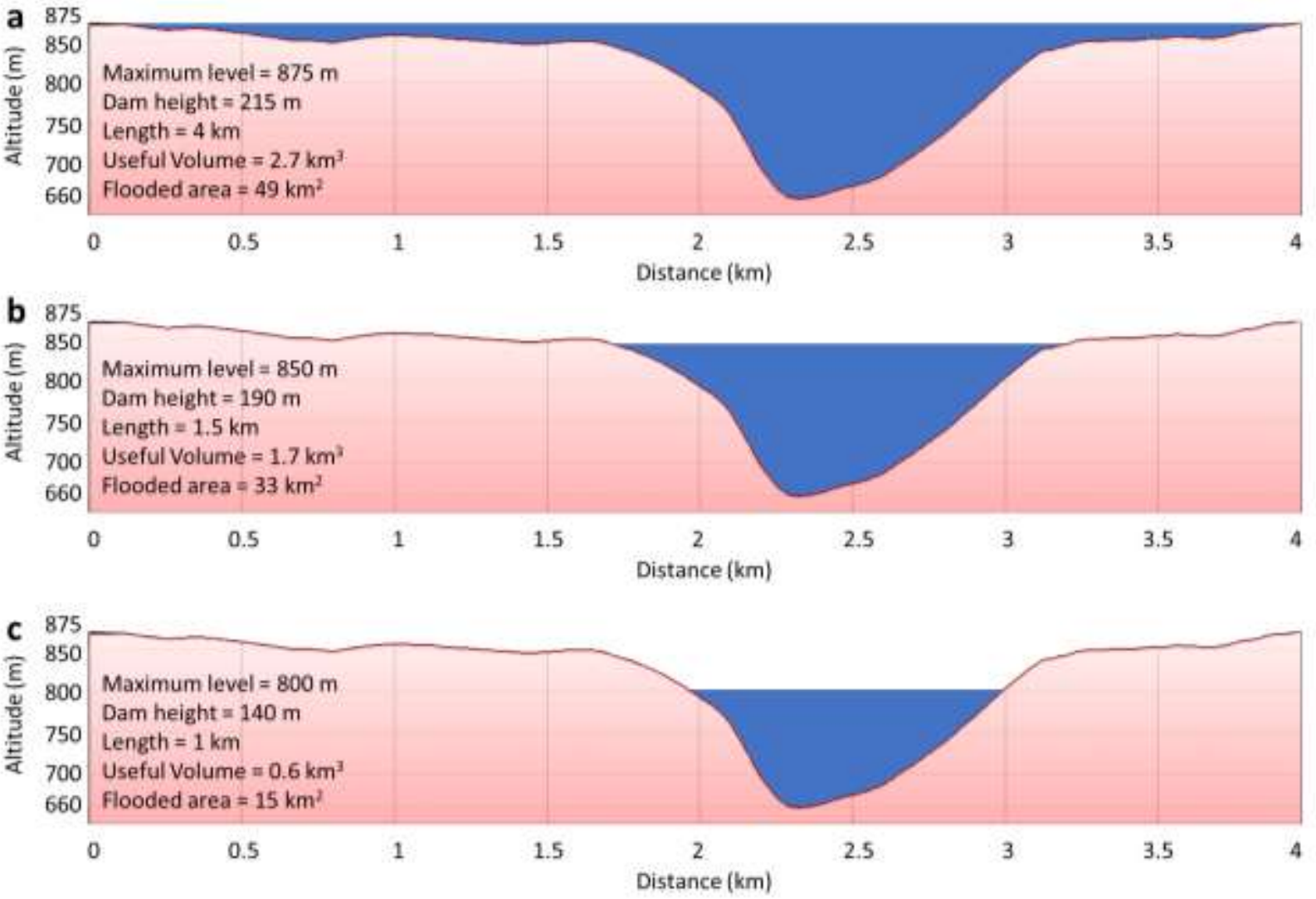

Figure 4: Different proposed heights for the São Tomé SPHS dam.

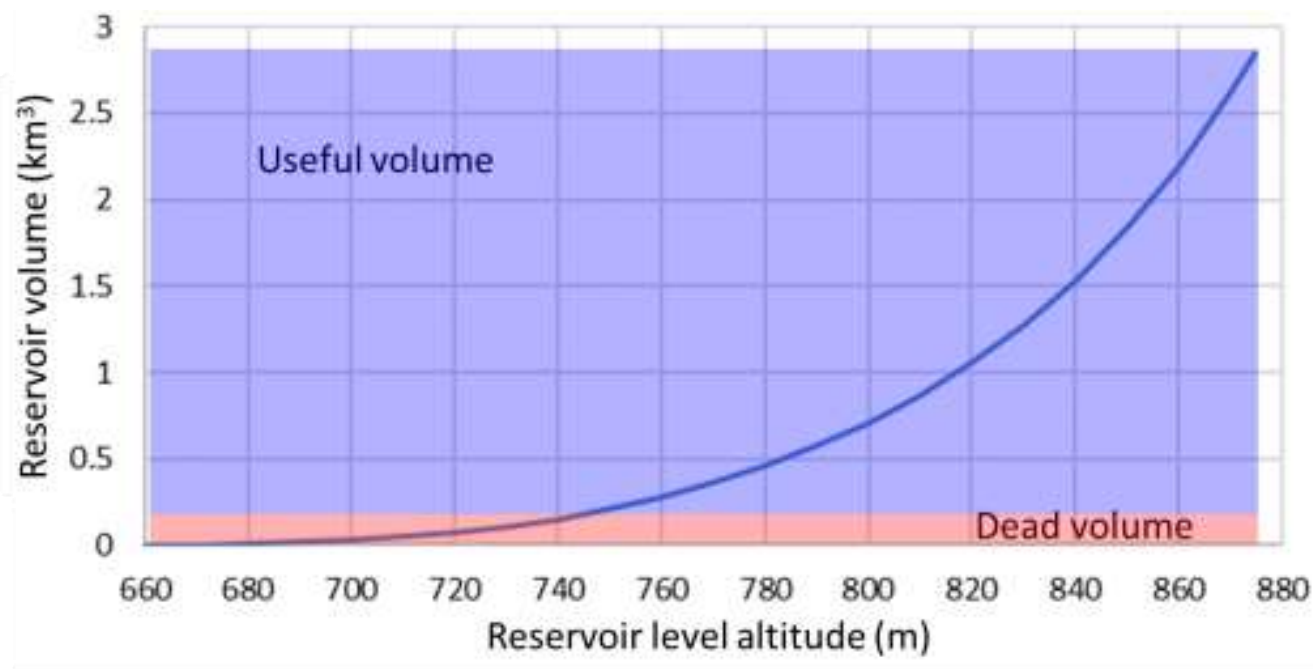

Figure 5. Volume level vs. storage volume curve for São Tomé SPHS.

Table 3. General benefits for the construction of the São Tomé SPHS in the SHPP and LHPP in cascade.

\begin{tabular}{|l|c|c|c|}
\hline \multicolumn{1}{|c|}{ Details } & Operating Plants & Planned Plants & $\begin{array}{c}\text { São Tomé } \\
\text { SPSH }\end{array}$ \\
\hline SHPP installed capacity (MW) & 84 & 286 & - \\
\hline LHPP installed capacity (MW) & 395.2 & 579.5 & - \\
\hline Total installed capacity (MW) & 479.2 & 865.5 & 1,000 \\
\hline SHPP head (m) & 101.4 & 273.4 & - \\
\hline LHPP head (m) & 178.95 & 230.5 & - \\
\hline Total hydropower head (m) & 280.37 & 503.9 & 315 \\
\hline SHPP flooded area $\left(\mathrm{km}^{2}\right)$ & 3.91 & 11.94 & - \\
\hline
\end{tabular}




\begin{tabular}{|l|c|c|c|}
\hline LHPP flooded area $\left(\mathrm{km}^{2}\right)$ & 18.13 & 41.83 & - \\
\hline Total flooded area $\left(\mathrm{km}^{2}\right)$ & 2.04 & 53.77 & 33 \\
\hline SHPP cascade regulation index (\%) & 1.05 & 0.81 & - \\
\hline LHPP cascade regulation index (\%) & 0.39 & 0.35 & - \\
\hline Total cascade regulation index (\%) & 0.63 & 0.60 & - \\
\hline Increase in hydropower generation (MW) & 150.74 & 259.9 & - \\
\hline Power/Flooded area $\left(\mathrm{km}^{2} / \mathrm{MW}\right)$ & 0.062 & 0.046 & 0.033 \\
\hline
\end{tabular}

\section{DISCUSSION}

An impact assessment of the São Tomé SPHS plant has been carefully analyzed. The reservoir is located far from any environmental restriction zone and any other type of restriction zone imposed by federal, state or municipal governments. The biggest cause for concern is the Cazuza Ferreira community with a population of approximately 300 people. Cazuza Ferreira is at an altitude of 907 meters and the maximum level of São Tomé SPHS is 875 meters. With the construction of this SPHS, the community would not be flooded and no one would have to be relocated and the reservoir, when full, would be $1.5 \mathrm{~km}$ from the community, as shown in Figure 6.

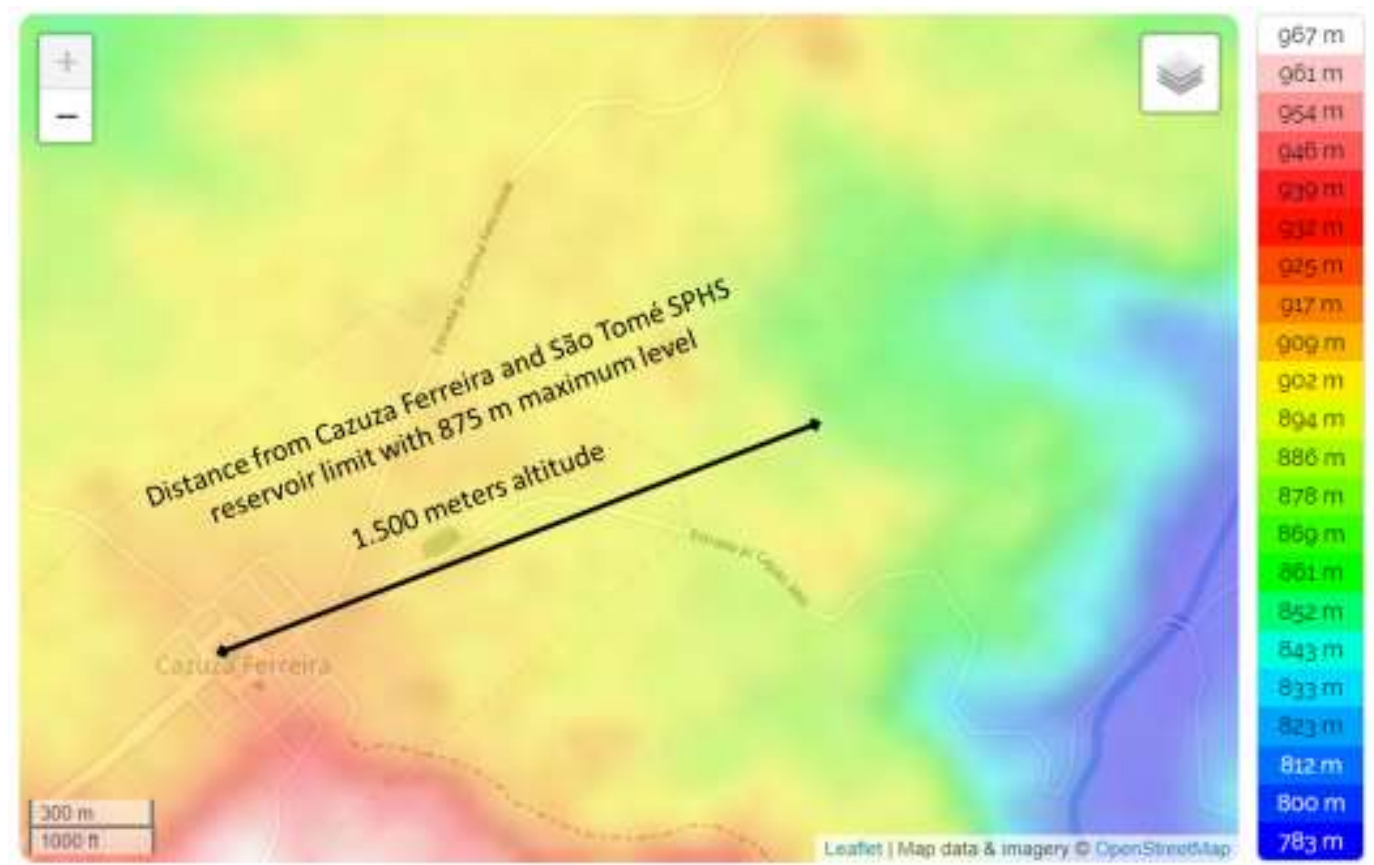

Figure 6. Impact of São Tomé SPHS on the Cazuza Ferreira community.

The map in Figure 7 presents the potential for daily, weekly, monthly, seasonal and pluri-annual PHS plants in and surrounding the Antas river basin. The methodology and model applied to find this potential is based on the Global SPHS potential model in (J. Hunt et al. 2020). Some adjustments were made to increase the number of seasonal PHS projects developed and to include daily and weekly PHS projects in the analysis. The exact São Tomé SPHS is not represented in Figure 7 because the model used to locate PHS projects assumes that the tunnel that connects the river and the SPHS reservoir connects directly to the SPHS dam, this is not the case for the São Tomé SPHS, as shown in Figure 1 (a). Figure 8 presents the topographic map of the Antas river basin, including all tunnels of the SPHS developed with the PHS mapping tool mentioned in the paper. 


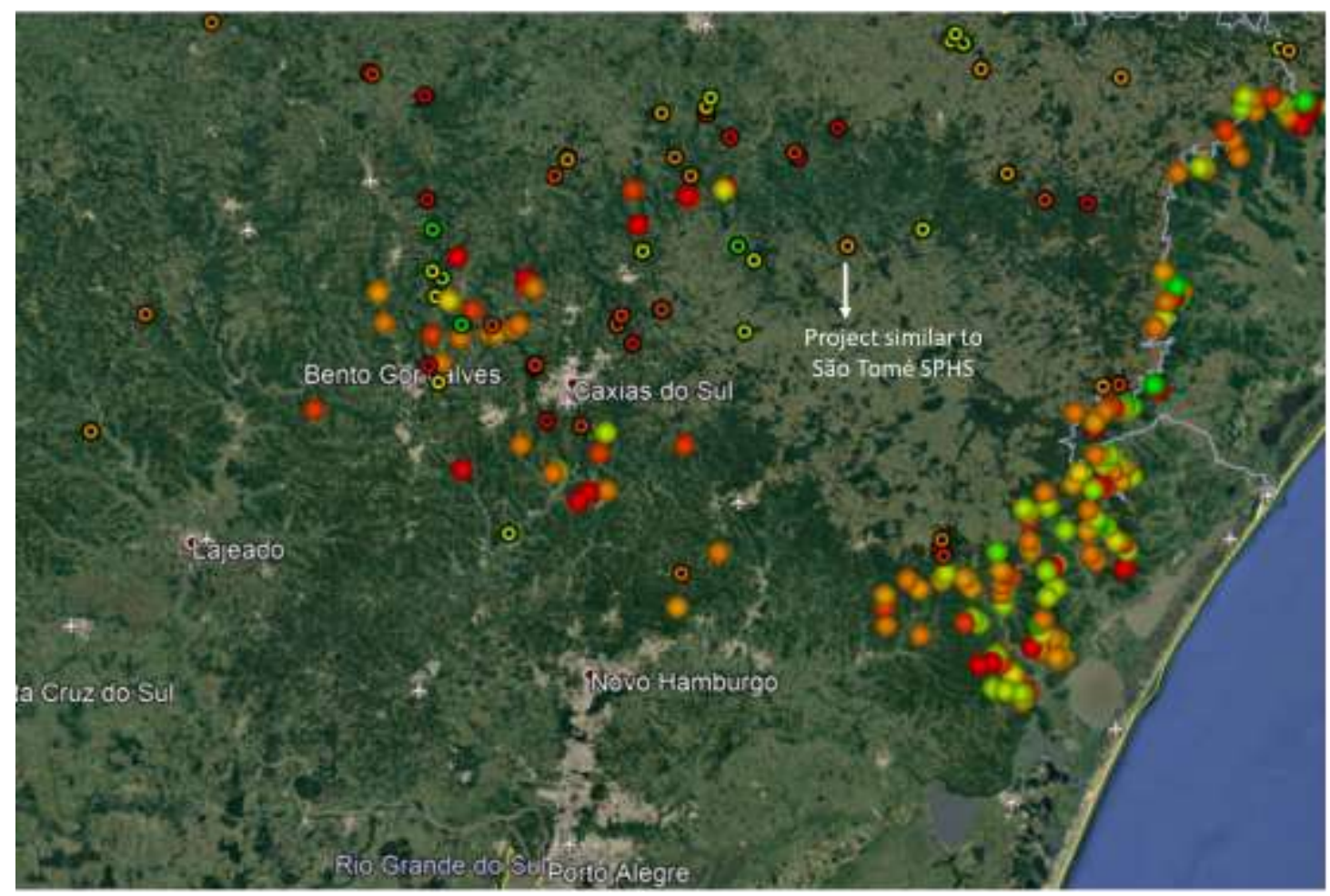

Figure 7. otential for daily, weekly, monthly, seasonal and pluri-annual PHS plants in and surrounding the Antas river basin.
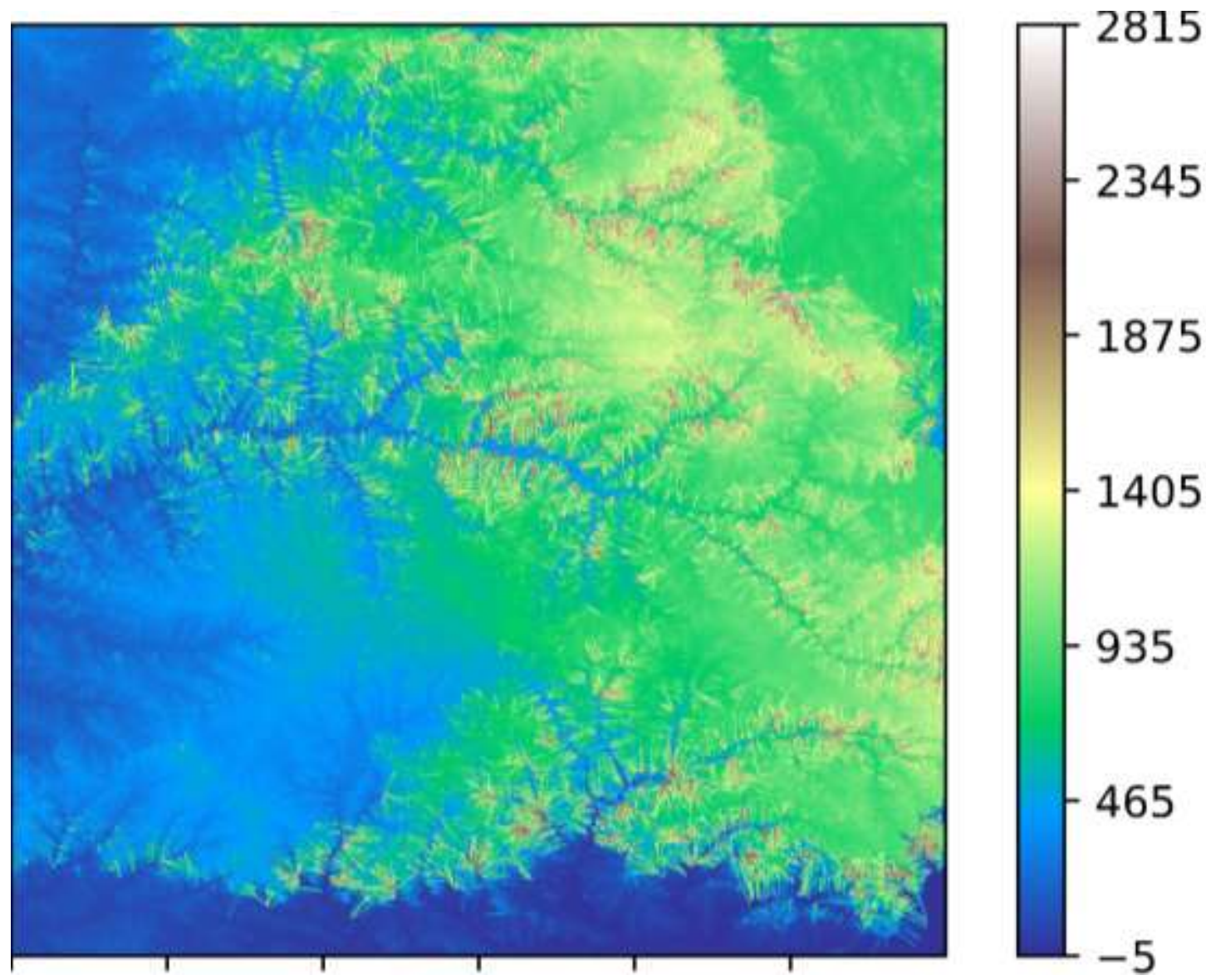

Figure 8. Topographic map of the Antas river basin, including the tunnels of the SPHS developed with the PHS mapping tool mentioned in the paper. 


\section{CONCLUSION}

This paper has shown the possibility of building seasonal pumped hydro storage plants in the Antas rives basin and described a possible project, named São Tomé SPHS. It also presented the possible benefits of SPHS, such as to regulate the flow of the river, reduce the spillage in dams in cascade downstream the SPHS, store energy from intermittent energy sources such as wind and solar, peak generation and store water for draught periods.

\section{ACKNOWLEDGEMENTS}

The authors would like to thank their funding sources. Julian David Hunt acknowledges PRINT/UFRGS/CAPES for the Visiting Professor position at the Programa de Pós-Graduação em Engenharia Mecânica - UFRGS; Natália de Assis Brasil Weber acknowledges CAPES for her research grant (88887.467463/2019-00); Lara Werncke Vieira acknowledges CAPES for her research grant (23038.000776/2017-54); Paulo Smith Schneider acknowledges CNPq for his research grant (301619/2019-0).

\section{REFERENCES}

Dallinger, B, D Schwabeneder, G Lettner, and H Auer. 2019. "Socio-Economic Benefit and Profitability Analyses of Austrian Hydro Storage Power Plants Supporting Increasing Renewable Electricity Generation in Central Europe." Renewable and Sustainable Energy Reviews 107: 482-96. https://doi.org/10.1016/j.rser.2019.03.027.

Griggs, D, M Stafford-Smith, O Gaffney, J Rockström, M C Öhman, P Shyamsundar, W Steffen, G Glaser, N Kanie, and I Noble. 2013. "Policy: Sustainable Development Goals for People and Planet." Nature 495 (7441): 305-7. https://doi.org/10.1038/495305a.

Huertas-Hernando, Daniel, Hossein Farahmand, Hannele Holttinen, Juha Kiviluoma, Erkka Rinne, Lennart Söder, Michael Milligan, et al. 2017. "Hydro Power Flexibility for Power Systems with Variable Renewable Energy Sources: An IEA Task 25 Collaboration.” Wiley Interdisciplinary Reviews: Energy and Environment 6 (1): e220. https://doi.org/10.1002/wene.220.

Hunt., J.D., D. Stilpen, and M.A.V. de Freitas. 2018. “A Review of the Causes, Impacts and Solutions for Electricity Supply Crises in Brazil." Renewable and Sustainable Energy Reviews 88. https://doi.org/10.1016/j.rser.2018.02.030.

Hunt, J., E. Byers, K. Riahi, and S. Langan. 2018. "Comparison between Seasonal Pumped-Storage and Conventional Reservoir Dams from the Water, Energy and Land Nexus Perspective.” Energy Conversion and Management 166: 385-401.

Hunt, J., E. Byers, Y. Wada, S. Parkinson, D. Gernaat, S. Langan, D. Vuuren, and K. Riahi. 2020. “Global Resource Potential of Seasonal Pumped-Storage for Energy and Water Storage.” Nature Communications 11 (947): Article number: 947.

Hunt, J.D., M.A.V. Freitas, and A.O. Pereira Junior. 2014. "Enhanced-Pumped-Storage: Combining Pumped-Storage in a Yearly Storage Cycle with Dams in Cascade in Brazil." Energy 78. https://doi.org/10.1016/j.energy.2014.10.038.

Hunt, J.D., M.A.V.D. Freitas, and A.O. Pereira Junior. 2017. “A Review of Seasonal Pumped-Storage Combined with Dams in Cascade in Brazil.” Renewable and Sustainable Energy Reviews 70. https://doi.org/10.1016/j.rser.2016.11.255.

Hunt, Julian David, Behnam Zakeri, Rafael Lopes, Paulo Sérgio Franco Barbosa, Andreas Nascimento, Nivalde José de Castro, Roberto Brandão, Paulo Smith Schneider, and Yoshihide Wada. 2020. "Existing and New Arrangements of Pumped-Hydro Storage Plants." Renewable and Sustainable Energy Reviews 129: 109914.

International Hydropower Association. 2019. "Pumped Storage Tracking Tool." 2019. https://www.hydropower.org/hydropower-pumped-storage-tool.

Jarvis A., H.I. Reuter, A. Nelson, E. Guevara. 2008. “Hole-Filled Seamless SRTM Data V4.” International Centre for Tropical Agriculture (CIAT). 2008.

Kong, Y, Z Kong, Z Liu, C Wei, J Zhang, and G An. 2017. "Pumped Storage Power Stations in China: The Past, the Present, and the Future." Renewable and Sustainable Energy Reviews 71: 720-31. https://doi.org/10.1016/j.rser.2016.12.100.

Kougias, I., and S. Szabó. 2017. "Pumped Hydroelectric Storage Utilization Assessment : Forerunner of Renewable Energy Integration or Trojan Horse?” 140: 318-29. https://doi.org/10.1016/j.energy.2017.08.106.

Kougias, Ioannis, George Aggidis, François Avellan, Sabri Deniz, Urban Lundin, Alberto Moro, Sebastian Muntean, et al. 2019. "Analysis of Emerging Technologies in the Hydropower Sector." Renewable and Sustainable Energy Reviews 113: 109257. https://doi.org/https://doi.org/10.1016/j.rser.2019.109257.

NHA. 2017. "Challenges and Opportunities For New Pumped Storage Development: A White Paper Developed by 
NHA's Pumped Storage Development Council."

Rasul, G, and B Sharma. 2016. "The Nexus Approach to Water-Energy-Food Security: An Option for Adaptation to Climate Change." Climate Policy 16 (6): 682-702. https://doi.org/10.1080/14693062.2015.1029865.

Ringler, C, A Bhaduri, and R Lawford. 2013. "The Nexus across Water, Energy, Land and Food (WELF): Potential for Improved Resource Use Efficiency?” Current Opinion in Environmental Sustainability 5 (6): 617-24. https://doi.org/10.1016/j.cosust.2013.11.002.

Schill, Wolf-Peter, and Alexander Zerrahn. 2018. "Long-Run Power Storage Requirements for High Shares of Renewables: Results and Sensitivities." Renewable and Sustainable Energy Reviews 83: 156-71. https://doi.org/https://doi.org/10.1016/j.rser.2017.05.205.

\section{RESPONSIBILITY NOTICE}

The author(s) is (are) the only responsible for the printed material included in this paper. 